\title{
FERMENTATION OF SWEET WHEY BY RECOMBINANT ESCHERICHIA COLI KO11
}

\author{
Amarildo Ricardo Leite; Walter Vieira Guimarães*; Elza Fernandes de Araújo; Daison Olzany Silva
}

Departamento de Microbiologia, Universidade Federal de Viçosa, Viçosa, MG, Brasil

Submitted: September 23, 1999; Returned to authors for corrections: June 05, 2000; Approved: September 13, 2000

\begin{abstract}
The production of ethanol from sweet whey using the recombinant Escherichia coli KO11, in batch fermentation, was tested. The maximum ethanol yield was reached after $96 \mathrm{~h}$, representing only $38 \%$ of the theoretical yield. The supplementation of whey with components of LB broth increased the maximum yield to $96 \%$ in $72 \mathrm{~h}$. The addition of $0.5 \%$ yeast extract to whey resulted in maximum yield of $74 \%$ at $36 \mathrm{~h}$ and it increased to over $100 \%$ when yeast extract and trace metals solution $\left(\mathrm{Fe}^{++}, \mathrm{Mn}^{++}\right.$and $\left.\mathrm{Zn}^{++}\right)$were added.
\end{abstract}

Key words: Escherichia coli, sweet whey, ethanol

\section{INTRODUCTION}

Sweet whey, a potent pollutant, is produced in large quantities by cheese industries and in most cases is discharged without any treatment to rivers or streams $(3,6,8)$. In Brazil, production of whey is estimated to be around 3 million tons per year (19). The pollution caused by whey is due essentially to the lactose content of the product $(6,13)$. Fermentation of whey by microorganisms is one possible way of reducing the pollutant effect. Several organisms have been tested for whey fermentation, however, the ethanol production, in general, is low $(5,12,17,16)$. Attempts to improve the ethanol yield from lactose fermentation have been made $(1,10,18)$. The development of the recombinant DNA technology made possible the construction of new strains capable of expressing genes originated from other organisms. Constructed plasmids, containing the genes $p d c$ (pyruvate decarboxylase) and $a d h B$ (alcohol dehydrogenase II) from Zymomonas mobilis, an efficient natural ethanol producer, were transfered to Escherichia coli (11). These genes are involved in ethanol pathway: the $p d c$ gene codes for pyruvate decarboxylase which is responsible for the decarboxylation of pyruvate to acetaldehyde and the gene $a d h B$ codes for the alcohol dehydrogenase II which reduces acetaldehyde to ethanol. $E$. coli transformed with these genes was able to ferment several substrates with high efficiency (1). The recombinant $E$. coli KO11 was used for whey fermentation and the supplementation of whey with ammonium sulfate and trace metals resulted in efficient ethanol production $(10,15)$.

In the present work, E. coli KO11 was tested for fermentation of whey supplemented with two different nitrogen sources and with some trace-metal combinations.

\section{MATERIALS AND METHODS}

The recombinant and ethanologenic E. coli KO11 was used for whey fermentation. The stock culture was stored at $-20^{\circ} \mathrm{C}$ in LB agar with $10 \mathrm{~g} / \mathrm{L}$ glucose, $40 \mathrm{mg} / \mathrm{L}$ chloramphenicol and $40 \%$ glycerol. For inoculum preparation, a single colony from LB agar plate was transferred to LB broth containing $10 \%$ glucose and $40 \mathrm{mg} / \mathrm{L}$ chloramphenicol. After overnight incubation at $30^{\circ} \mathrm{C}$ the cell concentration was measured in a spectrophotometer at $550 \mathrm{~nm}$ and the volume needed to prepare an inoculum of $0.1 \mathrm{OD}$ in the beginning of the fermentation was determined.

Two liters of ultra-filtered whey were autoclaved at $110^{\circ} \mathrm{C}$ for $15 \mathrm{~min}$ and kept at room temperature for 14-16h. Samples of $300 \mathrm{ml}$ of the supernatant were transferred to sterile Erlenmeyers and $40 \mathrm{mg} / \mathrm{L}$ chloramphenicol and the inoculum ( 0.1 final OD) were added. The fermentation was conducted at $30^{\circ} \mathrm{C}$ for $96 \mathrm{~h}$ with stirring at $100 \mathrm{rpm}$. The $\mathrm{pH}$ was maintained at minimum 6.0 by automatic addition of $2 \mathrm{~N} \mathrm{KOH} \mathrm{(2).}$

When needed, whey was supplemented with the components of LB broth or 0.05 to $0.5 \%$ of yeast extract or

\footnotetext{
* Corresponding author. Mailing addres: Departamento de Microbiologia, Universidade Federal de Viçosa, CEP 36571-000 - Viçosa, MG, Brasil. arleite@mailctu.ufjf.br
} 
0.01 to $0.2 \%$ ammonium sulfate and $5 \mathrm{ml} / \mathrm{L}$ of a trace metal mixture and/or $1 \mathrm{ug} / \mathrm{L}$ of thiamine. The trace metal mixture consisted of 100x concentrated solution containing per liter: $5 \mathrm{~g}$ disodium EDTA, $0.22 \mathrm{mg}$ zinc sulfate $\left(7 \mathrm{H}_{2} 0\right), 0.5 \mathrm{~g}$ calcium chloride, $0.5 \mathrm{~g}$ manganese chloride, $0.5 \mathrm{~g}$ ferrous sulfate, $0.1 \mathrm{~g}$ ammonium molybdate $\left(4 \mathrm{H}_{2} 0\right), 0.16 \mathrm{~g}$ cupric chloride, and $0.16 \mathrm{~g}$ cobalt chloride (10).

During $96 \mathrm{~h}$, at $12 \mathrm{~h}$ intervals, $1 \mathrm{~mL}$ of the fermentation medium was removed for ethanol determination. The samples were centrifuged $2 \mathrm{~min}$. in Eppendorf microcentrifuge. The supernatants were transferred to sterile Eppendorf tubes and kept at $-20^{\circ} \mathrm{C}$ in freezer for ethanol and residual sugar determinations. The ethanol concentration was determined in a gas chromatograph, Model CG-37D, using a porapak Q packed column. The column temperature was set at $190^{\circ} \mathrm{C}$, detector at $210^{\circ} \mathrm{C}$ and oven at $190^{\circ} \mathrm{C}$. Isopropanol was used as the internal standard. The concentration of lactose in the beginning and in the end of the fermentation was determined by the glucose oxidase method (GOD-PAP) $\left(\right.$ Merck $\left.^{\circledR}\right)$.

\section{RESULTS AND DISCUSSION}

The fermentation of whey, without supplements, resulted in low ethanol production (Fig. 1). The maximum ethanol production $(8.3 \mathrm{~g}$ ethanol/L) was observed at $96 \mathrm{~h}$, representing $38 \%$ of the theoretical yield. It has been reported that the lactose concentration of whey is around 5\% and protein around $0.9 \%$

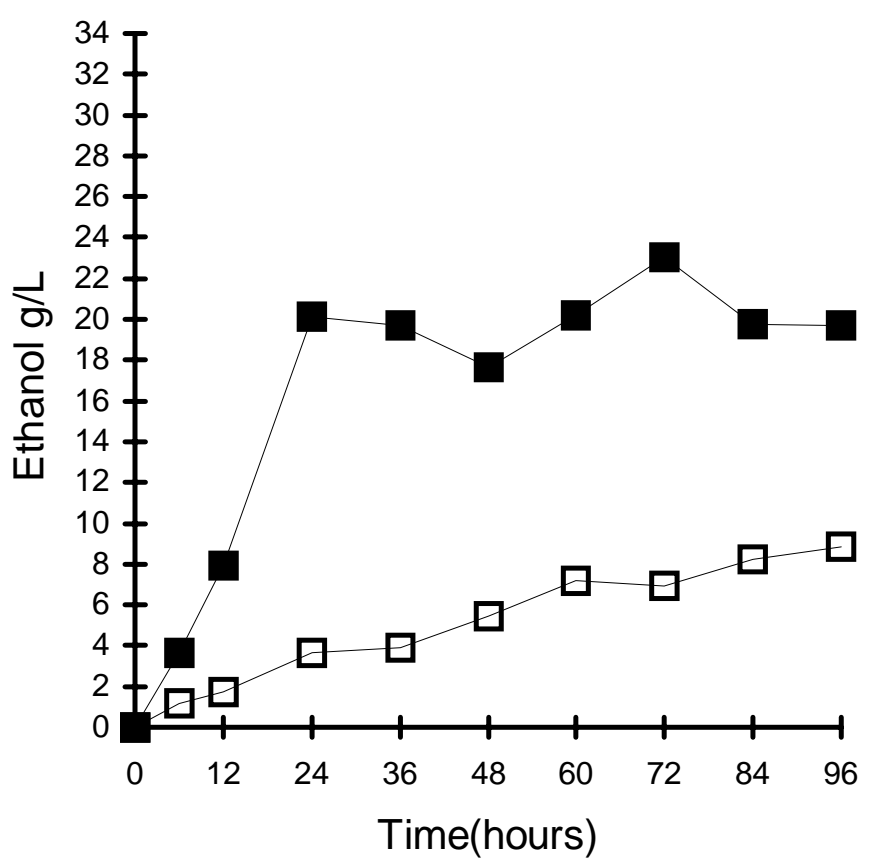

Figure 1: Production of ethanol by recombinant Escherichia coli KO11 during fermentation of whey $(\square)$ and whey suplemented with LB components (ם).
$(7,9,18)$. The limiting factor for whey fermentation by $E$. coli is essentially the nitrogen, because protein is not an available nitrogen source for this organism. In order to improve whey fermentation by recombinant $E$. coli, addition of different nutrients to the medium has been recommended (10). The supplementation with components of LB broth resulted in high ethanol yield (Fig. 1). Most of the lactose was used within $24 \mathrm{~h}$, resulting in $20.1 \mathrm{~g}$ ethanol/L and the maximum yield $(96 \%)$ was observed at $72 \mathrm{~h}$. Similar results have been reported for lactose fermentation and for whey fermentation $(1,10)$. Although the presence of amino acids in the LB constituents favors the fermentation process, it is important to look for cheaper supplement sources. Guimaraes et al. (10) observed that supplementation of whey with ammonium sulfate and/or trace metals resulted in high ethanol yield. They also improved the process adding protease that converted proteins into amino acids an organic nitrogen source for $E$. coli (10). In the present study, four different concentrations of yeast extract (YE) and ammonium sulfate $\left(\mathrm{NH}_{4}^{+}\right)$were tested for whey fermentation. There was no difference in ethanol production when 0.05 to $0.2 \%$ YE were added (Fig. 2). With $0.5 \%$ YE, the ethanol yield was higher and at $36 \mathrm{~h}$ it corresponded to $74 \%$ of the theoretical yield. Similar effect was observed in whey supplemented with $\mathrm{NH}_{4}^{+}$(Fig. 3). Addition of $\mathrm{NH}_{4}^{+}$up to $0.1 \%$ resulted in less ethanol production than addition of $0.2 \% \mathrm{NH}_{4}^{+}$. In this last case, the maximum yield $(62 \%)$ was reached at 72h. These results indicated that supplementation with $0.5 \%$

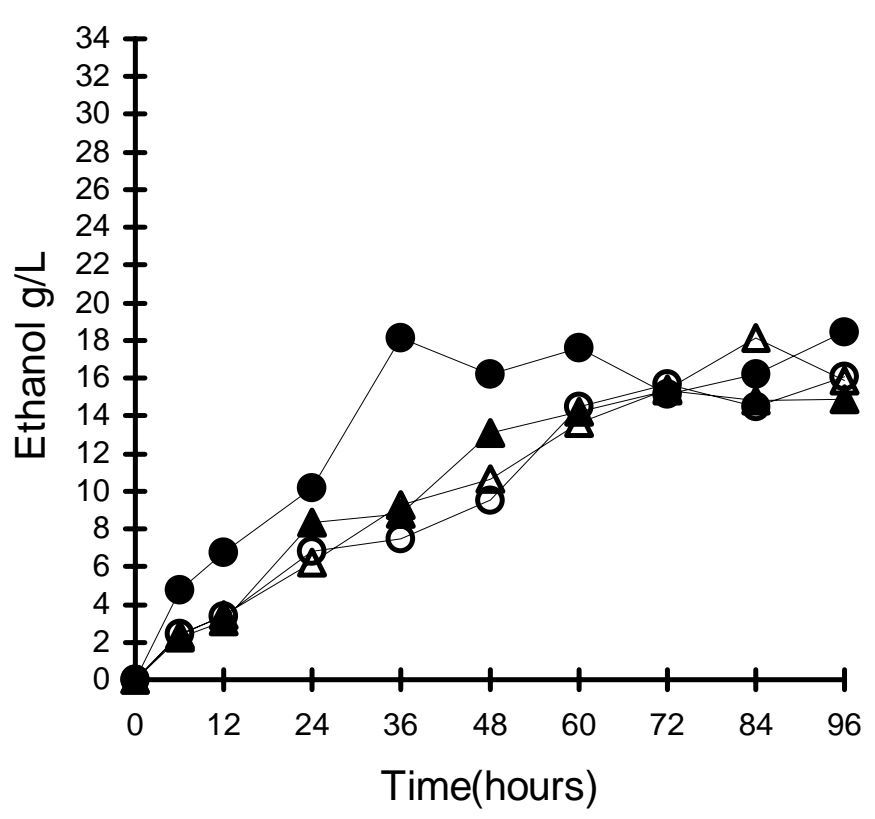

Figure 2: Production of ethanol by recombinant Escherichia coli KO11 during fermentation of whey supplemented with $0.5 \%(\bullet)$, $0.2 \%(\mathbf{\Delta}), 0.1 \%(\Delta)$ and $0.05 \%(\mathrm{O})$ yeast extract. 


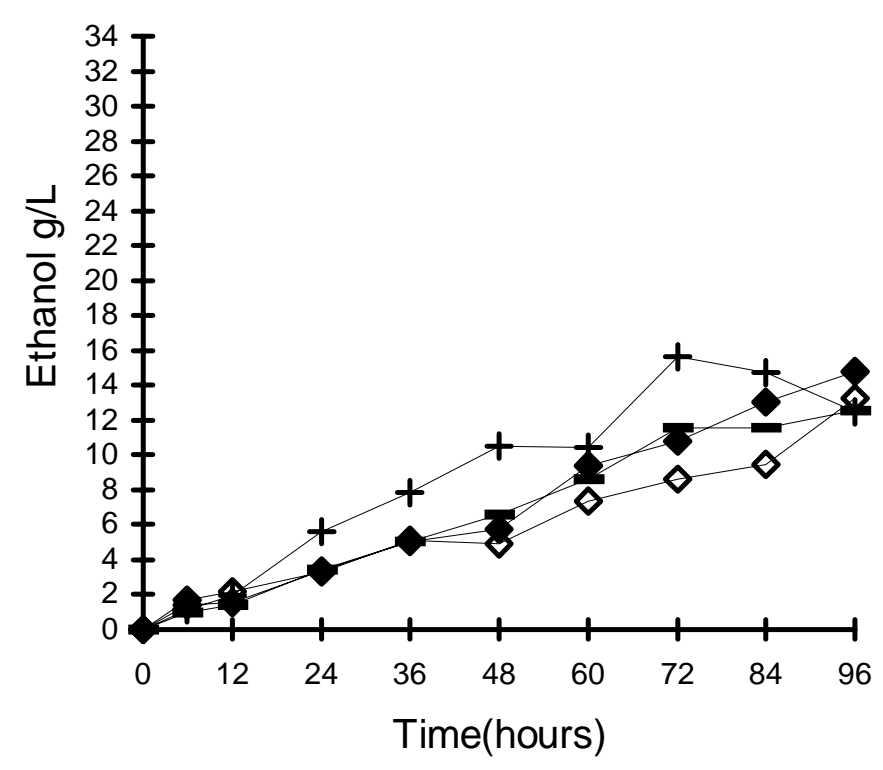

Figure 3: Production of ethanol by recombinant Escherichia coli KO11 during fermentation of whey supplemented with $0.2 \%(+), 0.1 \%(\diamond)$, $0.05 \%(-)$ and $0.01 \%(\diamond)$ ammonium sulfate.

YE or $0.2 \% \mathrm{NH}_{4}^{+}$almost doubled the ethanol production. However, the yield was lower than that obtained with addition of all LB components. The supplementation of whey with $0.5 \%$ meat extract was also tested but the ethanol production was lower than supplementation with $0.5 \%$ yeast extract (results not shown).

Trace metals and thiamine (Thi) are important for efficient fermentation by $E$. coli $(2,10)$. Some trace metals can act as cofactors for enzymes, others as constituents of compounds and others in oxi-reduction reactions $(4,14)$. According to Beall et al. (2), addition of $\mathrm{Mg}^{++}, \mathrm{Ca}^{++}$and $\mathrm{Fe}^{++}$to the medium increased the ethanol yield. Guimaraes et al. (10) reported that trace metals were important for whey fermentation by KO11. In order to improve the ethanol yield, combinations of trace metals were added to whey supplemented with $0.5 \%$ YE or $0.2 \% \mathrm{NH}_{4}^{+}$(Fig. 4). Addition of $\mathrm{Zn}^{++}, \mathrm{Mn}^{++}, \mathrm{Ca}^{++}$and Thi to whey containing $0.5 \% \mathrm{YE}$ resulted in higher ethanol production, corresponding to $86 \%$ of theoretical yield in $24 \mathrm{~h}$ when compared to whey supplemented only with $0.5 \%$ YE but no trace metals. In whey supplemented with $0.2 \% \mathrm{NH}_{4}^{+}$and trace metals, the highest ethanol production was observed when combination of $\mathrm{Fe}^{++}, \mathrm{Mn}^{++}$and $\mathrm{Zn}^{++}$was used. $\mathrm{Ca}^{++}, \mathrm{Mo}^{++}$and $\mathrm{Cu}^{++}$were less important in whey fermentation but the absence of $\mathrm{Zn}^{++}$affected the ethanol production. The positive effect of trace metals was only noted in the presence of a nitrogen source. It can be concluded that addition of $0.5 \% \mathrm{YE}$ and $\mathrm{Zn}^{++}, \mathrm{Ca}^{++}$,

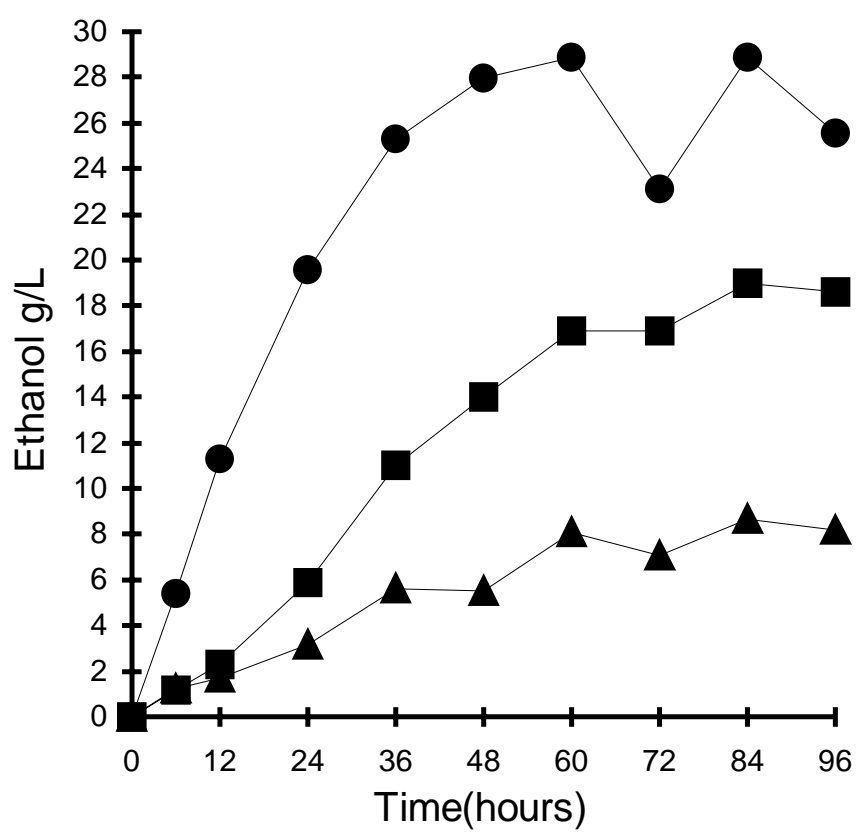

Figure 4: Production of ethanol by recombinant Escherichia coli KO11 during fermentation of whey supplemented with yeast extract $+\mathrm{Zn}+$ $\mathrm{Mn}+\mathrm{Ca}+$ Thiamine $(\bullet), \mathrm{NH}_{4}{ }^{+} \mathrm{Fe}+\mathrm{Mn}+\mathrm{Zn}(\boldsymbol{\bullet}),+\mathrm{Zn}+\mathrm{Fe}+\mathrm{Mo}+$ $\mathrm{Mn}+\mathrm{Ca}+\mathrm{Co}+\mathrm{Cu}+$ Thiamine $(\boldsymbol{\Delta})$.

$\mathrm{Mn}^{++}$and Thi to whey increased the ethanol production to a higher level than that obtained with whey supplemented with LB components.

\section{ACKNOWLEDGEMENTS}

This work was supported by grants from CAPES and FINEP/ FNDCT (Brazil).

\section{RESUMO \\ Fermentação de soro de leite por Escherichia coli KO11 recombinante}

A produção de etanol a partir de soro de leite empregando a cepa Escherichia coli KO11 recombinante, em fermentação de batelada, foi testada. O rendimento máximo de etanol foi obtido em 96h, representando apenas $38 \%$ do rendimento teórico. A suplementação do soro com os componentes do caldo LB aumentou o rendimento para $96 \%$ em $72 \mathrm{~h}$. A adição de $0,5 \%$ de extrato de levedura ao soro resultou em um rendimento máximo de $74 \%$ em 36 h que aumentou para acima de $100 \%$ quando se adicionou extrato de levedura e uma solução de metais traço $\left(\mathrm{Fe}^{++}, \mathrm{Mn}^{++}\right.$e $\left.\mathrm{Zn}^{++}\right)$.

Palavras-chave: Escherichia coli, soro de leite, etanol 


\section{REFERENCES}

1. Alterthum, F.; Ingram, L. O. Efficient Ethanol Production from Glucose, Lactose, and Xylose by Recombinant Escherichia coli. Appl. Environ. Microbiol., 55: 1943-1948, 1989

2. Beall, D. S.; Otha, K.; Ingram, L. O. Parametric Studies of Ethanol Production from Xylose and Other Sugars by Recombinant Escherichia coli. Biotechnol. Bioeng., 38: 296-303, 1991.

3. Ben-Hassan, R. M.; Ghaly, A. E. Continuous Propagation of Kluyveromyces fragilis Cheese Whey for Pollution Potential Reduction. Appl. Biochem. Biotechn. 47: 89-105, 1994.

4. Brock, T. D., Madigan, M. T., Martinko, J. M., Parker, J. Biology of microorganisms. Prentice-Hall Intern. Inc. Englewood Cliffs, New Jersey, 1994, 909p

5. Farahnak, F.; Seki, T.; Ryu, D. D.Y.; Ogrydziak, D. Construction of lactoseassimilating and high-ethanol-producing yeast by protoplast fusion. Appl. Environ. Microbiol., 51: 362-367, 1986.

6. Ferrat, A. Como valorizar o subproduto das fábricas de queijos, o "Lactosoro". Boletim do leite. 618: 32-38, 1980.

7. Gawel, J.; Kosikowski. Improving alcohol fermentation in concentrated ultrafiltration permeates of cottage cheese whey. J. Food Sci. 43: 1717-1719, 1978.

8. Ghaly, A . E.; Singh, R. K. Pollution potencial reduction of cheese whey through yeast fermentation. Appl. Biochem. Biotechnol., 22: 181-203, 1989.

9. Glass, L.; Hedrick, T. I. Nutritional composition of sweet and acid-type dry wheys. Vitamin, mineral, and calorie contents. J. Dairy Sci., 60: 190-196, 1976.
10. Guimarães, W. V.; Dudey, G. L.; Ingram, L. O. Fermentation of sweet whey by ethanologenic Escherichia coli. Biotechnol. Bioeng., 40: 41-42, 1992.

11. Ingram, L.O.; Conway, T. Expression of diferents levels pf ethanologen enzymes from Zymomonas mobilis in recombinants strains of Escherichia coli. Appl. Environ. Microbiol., 54: 397-404, 1988.

12. Janssens, J. H.; Bernard, A.; Bailey, R. B. Ethanol from whey: continuous fermentation with cell recycle. Biotechnol. Bioeng., 26: 01-05, 1984.

13. Juengst, F. W. J. Use of total whey constituents - Animal feed. J. Dairy Sci., 62: 106-111, 1979

14. Neidhardt, F. C.; Ingraham, J. K. L.; Schaechter, M. Physiology of the bacterial cell. A molecular approach. ASM, Washington, 1990, 507p.

15. Otha, K.; Beall, D. S.; Mejia, J. P.; Shanmugam, K. T.; Ingram, L. O genetic improvement of Escherichia coli for ethanol production: chromossomal integration of Zymomonas mobilis genes encoding pyruvate descarboxilase e alchool dehydrogenase II. Appl. Environ. Microbiol., 57: 893-900, 1991.

16. Porro, D.; Martegani, E.; Ranzi, B. M. Lactosel whey utilization and ethanol production by transformed Saccharomyces cerevisae cells. Biotechnol. Bioeng., 29: 799-805, 1992.

17. Terrel, S. L.; Bernard, A.; Bailey, R. B. Ethanol from whey: continuous fermenttation with a catabolite repression-resistant Saccharomyces cerevisae mutant. Appl. Environ. Microbiol., 48: 577-580, 1984.

18. Zertuche, L.; Zall, R. R. Optimizing alcohol production from whey using computer technology. Biotechnol. Bioeng., 27: 547-554, 1985.

19. Zoccal, R. Leite em números. EMBRAPA-CNPGL, Belo Horizonte, 1994 $131 \mathrm{p}$. 